\title{
Methodical bases of rating of investment appeal of Ukraine rural areas
}

\section{Oleksandr Yatsenko}

\section{East European University of Economics and Management, Cherkasy, Ukraine}

\section{Keywords:}

Investment

Attractiveness

Development

Rural

Rating

Article history:

Received 15.03.2016

Received in revised

form 16.05.2016

Accepted 30.06.2016

\section{Corresponding \\ author:}

Oleksandr Yatsenko

E-mail:

JacenkoVM@

bigmir.net

\section{Abstract}

Introduction. The article deals with the problem of methodological and practical principles of rating evaluation of rural regions investment attractiveness.

Material and methods. It was studying the investment attractiveness of rural areas on the example of Ukraine regions. It was used synergistic method, the methods of integrated comparison and evaluation. It was used ranking approach, which is the most common for the evaluation of investment attractiveness using index-indicator system.

Results and discussion. The evaluation algorithm of investment attractiveness of the region was offered. It involves a sequence of actions by which the first three stages are preparative; the following four stages are the direct assessment rating of the region at different levels.

The assessment methodology investment and innovation attractiveness of regions was offered, which is based on the using of standardization and rating methods and the using of the comparison method too. The three-level index-indicator system of assessing the investment attractiveness of rural areas was offered. The first stage of which contains the performance component of investment potential, the second stage contains indicators of investment risk and the last stage contains the generalized indicators of investment attractiveness of regions.

On the basis of the rating, we have constructed the typology of rural areas. Rural areas are represented practically in all rating groups approximately in the same proportion in relation to the number of groups and thus represent investment environment indicators for all regions of Ukraine.

It is defined that the rural investment attractiveness in the majority depends on the social and economic development. The type of investment climate $2 \mathrm{~B}$ (average potential, moderate risk) includes 6 rural regions; the type 3B1 (reduced potential, moderate risk) includes 4 rural regions; the type 3B2 (great potential, moderate risk), $2 \mathrm{C}$ (average potential, high risk), $3 \mathrm{C} 1$ (reduced potential, high risk) and 3C2 (great potential, high risk) include 3 rural regions. The regions with the minimal risk (types $1 \mathrm{~A}, 2 \mathrm{~A}, 3 \mathrm{~A}, 1 \mathrm{~B})$ according to the calculations are not available.

Conclusion. Based on the analysis of the investment climate, the distribution of rural regions is represented according to the investment types. The typology of rural regions is based on the basis rating. 


\section{Introduction}

In the modern conditions of managing the competitive struggle for the attraction of additional capital sources for stabilization and economic development is constantly increasing. It is in the process at all economic levels, and especially at the mesolevel or the level of the regional economy. In the world practice of government regulation of the regional economy, funds are invested into the most powerful territorial and sectored groupings which, due to its rapid and profitable growth, help to support necessary market transformation in the areas with lower or slower level of development. It actualizes the theme of rating evaluation of investment attractiveness of regions. Moreover private investors' important issue is the choice of the most attractive areas of strategic management, investments into which will allow to recover and increase the initial capital, that to attract reinvested funds.

Realization of innovative projects, including the national project "State Target Program of Ukrainian Village Development for the Period up to 2015" provides more active investment policy. At the same time, the investment processes in agriculture continues to lag behind other industries. For the years of independence the investment policy of the government was not aimed at changing the current situation. Normative Acts aimed at intensifying of investment activities were not implemented. For example, the mentioned "State Target Program of Ukrainian Village Development for the Period up to 2015" was not financed and did not fully play the role designated to it. The analysis of the existing system of AIC state support shows that it is aimed primarily at solving current problems, and the strategic issues of agricultural development do not find the proper solution.

This policy has led to a decline in the share of fixed capital investments into agricultural production in Ukraine from $14.3 \%$ of the value of gross output in 1991 to $4.5 \%$ in 2010. The "the investment corridor" providing the optimal level of savings for the economy in general on a number of assessments should be $21-23 \%$ of GDP. In rural areas the share of investment in 2013 ranged from 0.5 to $16.4 \%$ of gross added value produced in agriculture (GVA in agriculture). More than $10 \%$ is in Lviv region (16.4\%), Chernihiv region (12.5\%), Cherkasy region (15.1\%), Kherson region (12.2\%), Mykolaiv region $(11.3 \%)$, Zhytomyr region (11, 5\%), Odessa and Zaporizhya regions (10.2\%). In Lugansk region it is $9.9 \%$. Less than $5 \%$ is Sumy region $(4.8 \%)$, Chernivtsi region $(4.6 \%)$, Transcarpathia region (4.3\%), Rivne region (4.1\%), the Crimean Republic $(3.9 \%)$. The remaining 12 rural areas have from 5 to $10 \%$. Thus, the existing level of investment in agriculture does not ensure the implementation of innovative projects and is unacceptably low even in the most rural regions referred to the group with the highest socio-economic development.

It is known that investment attractiveness is the integrating indicator of the investment climate in a region. In the implementation of the national rural development projects, a significant role is given to administrations, and therefore the investment attractiveness of the region is crucial in attracting investments.

\section{Analysis of recent research}

There is a great number of approaches to evaluate the investment attractiveness of regions, industries and individual businesses currently. Indicators of investment attractiveness are quite diverse and vary depending on the place of the subject in the relevant territorial, sector, management hierarchy. The rating approach is one of the most common in the evaluation practice of investment attractiveness of regions. This approach 
(in the variety of its modifications) is put into the basis of techniques, particularly those offered by such scientists as I. Blank [1], S. Sonko [2], A. Datsishin [3] etc., expert groups of the Institute of Reforms, "SOCIS Gallup International", RA "Expert Rating" and others. [4-8]. Authorities of Ukraine have developed the techniques in the direction of evaluation: methods of assessing the level of business activity in the region, which is developed by the Cabinet of Ministers of Ukraine [9]; methods of evaluation of investment attractiveness, approved by the Ministry of Economy and European Integration of Ukraine; the method of calculating the integrated regional indices of economic development adopted by the State Statistics Committee of Ukraine and others.

In regard to administrative entities and industries the investment attractiveness is determined by the investment climate, which is economic, political, financial conditions affecting the supply of domestic and external investments into the economy. According to the classification of A. Ageenko [10] all indicators of investment attraction and economic entity can be divided into two groups. The first group includes social indicators that characterize the political climate of the region, the environmental situation, demographics, ethnic relations, and others. These factors are not amenable to precise quantitative evaluation, linkage to a particular industry or organization. They characterize the region as a whole. Different researchers apply subjective expert methods to them when determining their impact on the overall potential economic entity. The second group is formed by economic factors contained in the official statistical and accounting records. They help to assess the production potential, financial results, investment activity, and labor potential of economic entity. The association of outlined set of multi-level indicators makes the information base for an integrated assessment of investment attractiveness of the rural region and its major subsystems.

\section{Material and methods}

It was studying the investment attractiveness of rural areas on the example of Ukraine regions.

It was used ranking approach, which is the most common for the evaluation of investment attractiveness using index-indicator system.

The evaluation algorithm of investment region attractiveness is proposed, which provides a certain sequence of actions, according to which the first three stages are preparatory, and the next four are the direct rating assessment of a region at different levels (at the level of individual indicators, their groups, associations of these groups and integrated region assessment). The suggested technique of an estimation of investment and innovation attractiveness of regions is based on the usage of the methods of standardization and regulation, as well as on the method of comparison. Synergistic and systematic approaches are used in the study as well.

\section{Result and discussion}

According to existing methods the investment climate of regional agents is evaluated on the basis of indicators of investment potential and investment risk. Investment potential takes into account basic macroeconomic characteristics, area saturation factors of production, consumer demand and other indicators. The value of the investment risk describes the probability of investments loss and income from them. When calculating the integrated rankings of a region by the investment potential and risk, expert assessments of potential components and risk are used as well as the rejection of risk components of a 
region on average. Final ratings define sequence numbers of regions so that the smaller the number, the higher potential and thus the lower risk (the first number corresponds to the highest potential and the lowest risk). In cases where the actual values of statistical parameters of several regions are the same, the entire group is assigned an average rating value.

The summary typology of regions based on the investment climate is offered in the following stratification:

Type 1 A. Maximum potential - minimum risk.

Type 2A. Average capacity - minimum risk.

Type 3A. Low potential - minimal risk.

Type 1B. High potential - moderate risk.

Type 2B. Medium potential - moderate risk.

Type 3B1. Decreased potential - moderate risk.

Type 3B2. Minor potential - moderate risk.

Type $2 \mathrm{C}$. Average capacity - high risk.

Type 3C1. Decreased potential - high risk.

Type 3C2. Minor potential - high risk.

Type 3D. Low potential - extreme risk.

For the current situation when it is necessary to develop investment policies at both the national and regional levels, it is important to evaluate how the introduced indicators and rankings affect the real actions of investors. This research was conducted by G. Untura [11]. The investment activity in the part of the actually made investments was measured by the size of domestic and, separately, foreign investments per capita of regions. These values served as dependent variables in the equation of regression where the independent variables were either investment potential or investment risk. Calculations, carried out on the materials of 1990-2013, for each year individually, revealed statistical dependency significance, increased reaction of investors on ratings given and adequate perception of them (with some lag). The expediency of regular adjustment of methods of ranking calculating with the change of socio-economic and political situation in the country was also noted. Among the shortcomings of the methodology the incomplete set of indicators which are calculated on the basis of ratings of regions' investment attractiveness and possible subjectivity of expert assessments in the indicator calculation have been marked.

In regard to the abovementioned, we proposed the algorithm for the evaluating of the region investment attractiveness, which provides a sequence of actions, according to which the first three stages are preparatory, and the next four are direct rating assessment of the region at different levels (at the level of individual indicators, their groups, associations of these groups and complex estimation of the region). Thus, the main stages of the proposed algorithm for evaluation of investment attractiveness of the region are:

1 - establishing of eight evaluation criteria of investment attractiveness of a region (its general economic development, financial support of the economy, innovation and investment and social development as well as the development of regional infrastructure, efficient use of production resources and business activity), forming of eight groups of indicators that correspond to the mentioned criteria (six groups of absolute indicators to characterize the level of socio-economic development of the region and two groups of relative indicators for the detection of the efficient usage of fixed types of resources in the region;

2 - identifying and averaging the actual level (or standardized values) of each of the output indicators used to evaluate the investment attractiveness of the region; 
3 - predicting the level of each of the normalized indices (indicators of investment attractiveness of the region), taking into account the dynamics of the actual values of these indices for the selected period;

4 - regions' ratings plotting of the studied population according to their investment attractiveness for each of the average actual and for each of the forecast values of the standardized indices;

5 - group rating plotting of areas for each of the selected criteria of the investment attractiveness based on the results calculated for each region of complex indicators which average actual and projected levels of investment attractiveness according to a particular group of indicators accordingly;

6 - plotting of general (or integrated) ratings of regions (individually for the characterization of socio-economic level supply of the region development according the first five groups of indicators and for the establishment of the efficiency level of fixed kinds of resources in the following two groups of indicators) on the basis of calculation of integrated indicators according to the totals of group value (actual and forecast) indicators of investment attractiveness, defined in the previous (the fifth) assessment stage;

7 - plotting of complex (or final) rating of areas through integrated indicators identified by combining the corresponding integral indicators of investment attractiveness.

The proposed method of estimating the investment and innovation attractiveness of regions is based on the use of methods of standardization and regulation, as well as on the method of comparison. In addition, in the study the synergistic and systematic approaches are used.

The only complexity in the implementation of the algorithm of the investment attractiveness of rural areas is to build a wider system of indicators characterizing the investment potential of the region, and the calculation of partial coefficients of risk investment activity within the rural area. Taking into account the research process and assessment of the attractiveness a three-tier system of indicators is formed (Table 1).

Based on the analysis of the investment climate, table 2 shows the distribution of rural areas according to investment types.

On the basis of the rating of 2012-2013, we have constructed the typology of rural areas. Rural areas are represented practically in all rating groups approximately in the same proportion in relation to the number of groups and thus represent investment environment indicators for all regions of Ukraine. Regions with low-risk (groups 1A, 2A, 3A, 1B) according to calculations are missing.

Analysis of Table 2 suggests that for rural areas investment attractiveness mostly depends on the level of socio-economic development. The highest investment attractiveness (type 3B1: Medium potential - moderate risk) is marked for the regions with the highest complex rating assessment of socio-economic development. The decrease in the level of socio-economic development is accompanied by the decrease in investment potential and growth of the investment risk. The decrease in the level of socio-economic development is accompanied by the decrease in investment potential and growth of the investment risk. In Table 3 it is shown by simultaneous movement of regions to the right and down. In particular, if the regions with the type of investment environment 3B1 (reduced potential moderate risk) are approximately evenly distributed between groups with differently rated socio-economic development, for the following types of investment environment the movement of regions into the lower groups of socio-economic development is observed, and all rural areas with the lowest investment climate (type $3 \mathrm{C} 2$ : little potential - high risk) are concentrated in the third worst group in the ranking of socio-economic development. 
Table 1

The system of index-indicators for assessing the investment attractiveness of a region

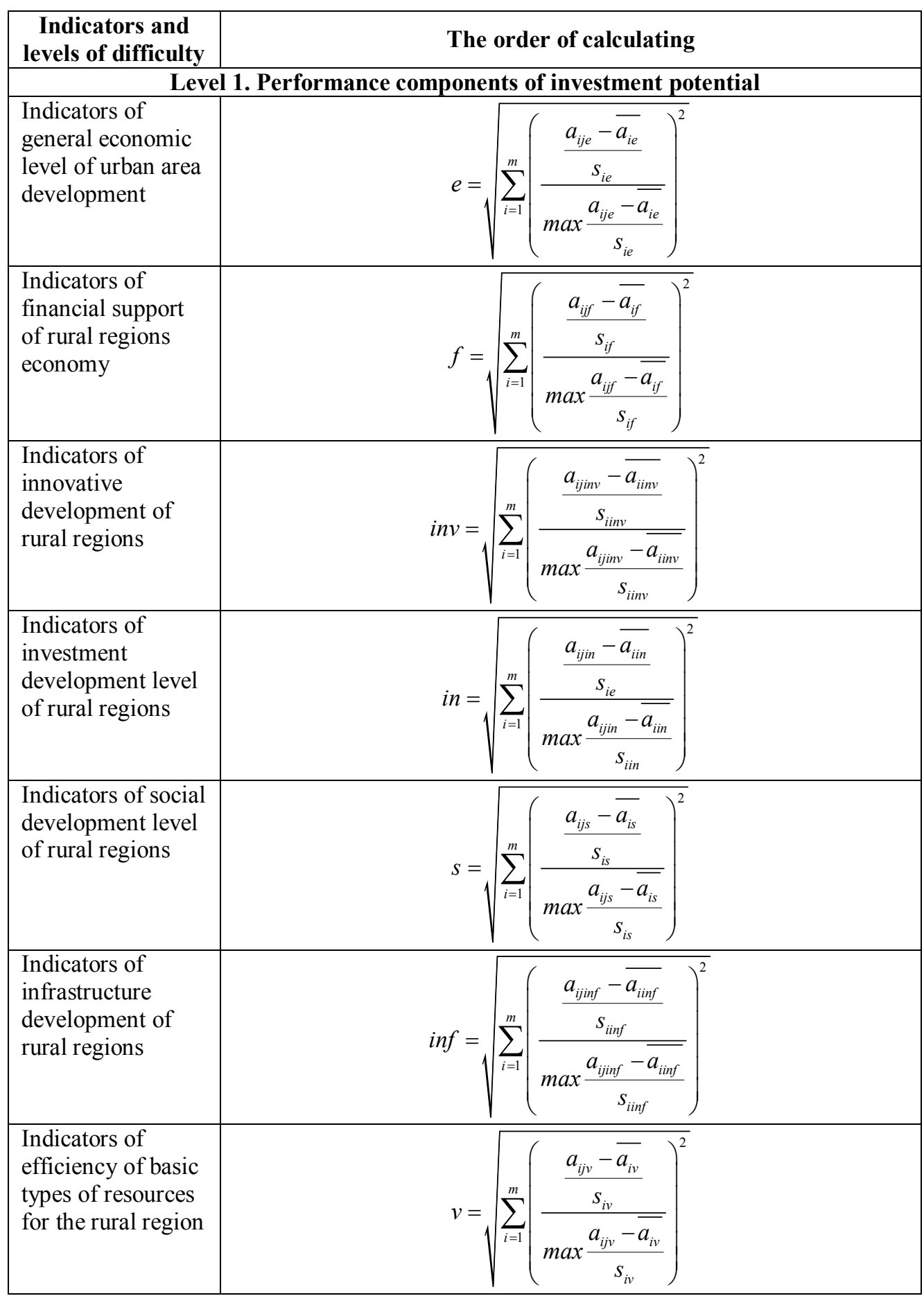




\begin{tabular}{|c|c|}
\hline $\begin{array}{l}\text { Indicators of } \\
\text { business activity of } \\
\text { the rural region }\end{array}$ & $b a=\sqrt{\sum_{i=1}^{m}\left(\frac{\left.\frac{a_{i j b a}-\overline{a_{i b a}}}{\max \frac{a_{i b a}-\overline{a_{i b a}}}{s_{i b a}}}\right)^{2}}{2}\right.}$ \\
\hline & Level 2. Indicators of investment risk \\
\hline $\begin{array}{l}\text { Economic risk } \\
\text { coefficient }\end{array}$ & 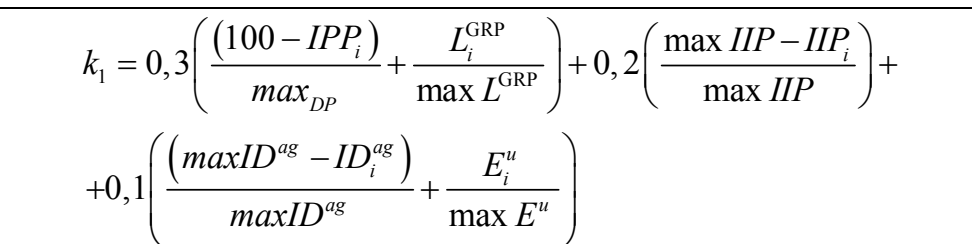 \\
\hline $\begin{array}{l}\text { Financial risk } \\
\text { coefficient }\end{array}$ & $k_{2}=0,1\left(\frac{P_{i}}{\max P}\right)+0,3\left(\frac{F_{i}^{d}}{\max F^{d}}\right)+0,2\left(\frac{L_{i}}{\max L}\right)+0,4\left(\frac{F R_{i}^{e}}{\max F R^{e}}\right)$ \\
\hline $\begin{array}{l}\text { Social risk } \\
\text { coefficient }\end{array}$ & $k_{2}=0,4\left(\frac{W_{i}}{\max W}\right)+0,2\left(\frac{U_{i}}{\max U}+\frac{E_{i}}{\max E}+\frac{\max G-G_{i}}{\max G}\right)$ \\
\hline $\begin{array}{l}\text { Legislative risk } \\
\text { coefficient }\end{array}$ & $\begin{array}{c}\text { Share of normative acts of the } i \text {-th region the total number of acts } \\
\text { regulating investment activities }\end{array}$ \\
\hline $\begin{array}{l}\text { Political risk } \\
\text { coefficient }\end{array}$ & $\begin{array}{l}\text { Percentage of individuals who supported the ruling party, the number } \\
\text { of people voting }\end{array}$ \\
\hline $\begin{array}{l}\text { External economic } \\
\text { risk coefficient }\end{array}$ & $k_{6}=0,2\left(\frac{I G_{i}^{U}}{\max I G^{U}}\right)+0,8\left(\frac{I G_{i}^{\mathrm{GRP}}}{\max I G^{\mathrm{GRP}}}\right)$ \\
\hline $\begin{array}{l}\text { Environmental risk } \\
\text { coefficient }\end{array}$ & $k_{7}=0,4\left(\frac{E H S_{i}}{\max E H S}\right)+0,3\left(\frac{H S_{i}^{\mathrm{km} 2}}{\max H S^{\mathrm{km} 2}}+\frac{H S_{i}^{\mathrm{p}}}{\max H S^{p}}\right)$ \\
\hline $\begin{array}{l}\text { Criminal risk } \\
\text { coefficient }\end{array}$ & $k_{8}=0,5\left(\frac{R_{i}}{\max R}+\frac{O_{i}}{\max O}\right)$ \\
\hline \multicolumn{2}{|c|}{ Level 3. Generalized indicators of investment attractiveness of a region } \\
\hline $\begin{array}{l}\text { Generalized } \\
\text { indicator of } \\
\text { investment } \\
\text { potential }\end{array}$ & $P=\frac{e+f+i n v+i n+s+\inf +r+b a}{8}$ \\
\hline $\begin{array}{l}\text { Generalized } \\
\text { indicator of } \\
\text { investment risk }\end{array}$ & $R=\frac{\sum_{i=1}^{n} k_{i}}{n}$ \\
\hline $\begin{array}{l}\text { Generalized } \\
\text { indicator of } \\
\text { investment } \\
\text { attractiveness }\end{array}$ & $I P=P \cdot(1-R)$ \\
\hline
\end{tabular}

Legend: $a_{\mathrm{ij}}$ - value of $i$-th index of the $j$-th region of corresponding components of investment and innovation capacity; $s_{\mathrm{i}}$-standard deviations of $a_{\mathrm{ij}}$ for corresponding 
component of investment and innovation capacity; $\bar{a}_{i}$ - average value of the $i$-th indicator of a corresponding component of investment potential; IIP $P_{i}$ index of industrial production of the $i$-th region, $\%$; $D P$ - the largest decline in production in the region; $L_{i}^{\mathrm{GRP}}$ - share of loss in GRP of the $i$-th region; $I D_{i}^{a g}$ - index of agricultural production development of the $i$-th region; $E_{i}^{u}$ - share of unprofitable enterprises of the $i$-th region; $P_{i}$ - level of enterprises profitability of the $i$-th region; $F_{i}^{d}$ - financial dependence of enterprises of the $i$-th region; $L_{i}$ - current enterprises liquidity of the $i$-th region; $F R_{i}^{e}-$ financial risk of enterprises of the $i$-th region; $W_{i}$ - the share of workers of the $i$-th region who took part in strikes, $\% ; U_{i}-$ unemployment rate, in $\%$ to the economically active population of the $i$-th region; $E_{i}$ - population number with an average income below the subsistence minimum in $\%$ to the total population of the $i$-th region; $G_{i}$-dynamics of the real money incomes of population, in $\%$ in comparison to the previous year of the $i$-th region; $I G_{i}^{U}$ - import of the $i$-th region in the total amount of imported goods to Ukraine, $\% ; \quad I G_{i}^{\mathrm{GRP}}$ - share of import in the economy of the $i$-th region; $E H S_{i}$ - emissions of harmful substances which into get into the atmosphere, in $\%$ of total of the $i$-th region; $H S_{i}^{\mathrm{km} 2}$ - amount of harmful substances per area of $1 \mathrm{~km}^{2}$ of the $i$-th region; $H S_{i}^{\mathrm{p}}-$ amount of harmful substances per 1 person of resident population of the $i$-th region; $R_{i}-$ share of persons prosecuted to the administrative responsibility, in an aggregate number of resident population of the $i$-th region, $\% ; O_{i}$ - index of number of offenses registered in the area of the $i$-th region, $\%$.

Distribution of rural areas by the type of investment environment

Table 2

\begin{tabular}{|c|c|l|}
\hline $\begin{array}{c}\text { Type of investment } \\
\text { climatey }\end{array}$ & $\begin{array}{c}\text { Number of } \\
\text { rural areas }\end{array}$ & \multicolumn{1}{|c|}{ Rural areas } \\
\hline 2B & 6 & $\begin{array}{l}\text { Regions: Donetsk, Dnipropetrovsk, Kyiv, } \\
\text { Lviv, Cherkasy, Mykolayiv }\end{array}$ \\
\hline 3B1 & 4 & Regions: Zhytomyr, Sumy, Luhansk, Poltava \\
\hline 3B2 & 3 & Regions: Chernihiv, Rivne, Kherson \\
\hline 2C & 3 & Regions: Odessa, Zaporizhzhya; Crimea \\
\hline 3C1 & 3 & $\begin{array}{l}\text { Regions: Vinnytsya, Transcarpathian region, } \\
\text { Kharkiv }\end{array}$ \\
\hline 3C2 & 3 & Regions: Volyn, Ivano-Frankivsk, Chernivtsi \\
\hline
\end{tabular}


Distribution of rural areas by the type of investment climate and ranking of socio-economic development

\begin{tabular}{|c|c|c|c|}
\hline \multirow{2}{*}{\begin{tabular}{c} 
Type of $\begin{array}{c}\text { investment } \\
\text { climate }\end{array}$ \\
\cline { 2 - 4 }
\end{tabular}} & 1 & 2 & 3 \\
\hline 3B1 & $\begin{array}{c}\text { Regions: Zhytomyr, } \\
\text { Poltava, Lugansk, Poltava, } \\
\text { Kyiv }\end{array}$ & $\begin{array}{c}\text { Regions: Rivne, } \\
\text { Kherson }\end{array}$ & $\begin{array}{c}\text { Regions: Odesa, } \\
\text { Vinnytsya }\end{array}$ \\
\hline 3B2 & Crimea, Chernihiv region & $\begin{array}{c}\text { Regions: } \\
\text { Zaporizhzhia, } \\
\text { Kharkiv, Chernivtsi }\end{array}$ & $\begin{array}{c}\text { Transcarpathian, } \\
\text { Lviv }\end{array}$ \\
\hline 2C & Donetsk region & & $\begin{array}{c}\text { Regions: } \\
\text { 3C1 }\end{array}$ \\
\hline 3C2 & Dnipropetrovsk region & & $\begin{array}{c}\text { Volyn, Ivano- } \\
\text { Frankivsk region }\end{array}$ \\
\hline
\end{tabular}

1 - the highest level of economic development of its own food supply and purchasing power of population;

2 - close to the Ukrainian national average of these indicators;

3 - the lowest indicator values.

It is also necessary to mention that Poltava, Cherkasy region are included in ten regions with the least integrated investment risks since 2006 (annually); in certain years there were the autonomous republic of Crimea, Kyiv, Luhansk, Zhytomyr regions; for 1-2 years Odesa, Vinnytsya regions. In other words, we have introduced factors and built classifications which are quite productive for the assessment of investment attractiveness of rural areas as well corresponded to the integral estimates, based on more complete system of indicators, including indicators that are rated expertly.

Reduction of investment risk is the main task of administrations of the regions represented in the three lower lanes in Table 3.

In recent years, it is the local levels of management which have become the most important factor in changes of the investment climate in the region. Revitalization of the regional strategies and programs development is accompanied by the creation of new tools and the improvement of methods of interaction with investors. According to survey results, investors traditionally believe that local "law" defines mostly the investment climate. Regional administrations define different forms of support for investors who realize their projects in the region.

\section{Conclusions}

Rating evaluation of investment attractiveness of a region is extremely important if taking into consideration a wide range of users and possibilities to use its results. These users are primarily private investors, for whom the set ratings will serve as indicators of current and future benefit indicators and weaknesses, opportunities and threats during the substantiation of investment capital directions into regional entities. Bodies of state and local government which manage the allocation of expenditure of respective budgets for investment purposes in different objects on the regional level will also be interested in an objective rating assessment of the region, because this approach will help them to justify 
the optimal structure of expenditures and increase economic efficiency of the budget use. In addition, the detection of complex problems and strong sides of certain regions in different areas for regional socio-economic development support and according to the efficiency level of the use of basic types of region resources can act as a reliable basis for the formulation and implementation of national programs and strategies for country development.

\section{References}

1. Blank I. A. (2003), Upravlenie investitsiyami predpriyatiya, Nika-Tsentr, Elga.

2. Sonko S. P. (2002), Rinok i regionalistika, NIka-Tsentr.

3. Datsishin A. M. (2003), Investitsiyniy reyting regioniv Ukrayini za pidsumkami 2003 roku, Prioritety, 9(15), pp. 25-33.

4. Duhnenko V. (2008), Reyting investitsionnoy privlekatelnosti regionov. V poiskah vnutrennego ryinka, Ekspert, 50, pp. 54-59.

5. Reyting regIonIv Ukrayini, RA “Ekspert-Reyting”, available at: http://www.expertrating.com.

6. (2006), Reyting investitsionnoy privlekatelnosti regionov Ukrainyi "Ekspert”, 49.

7. (2008), Reyting investitsiynoyi privablivosti regioniv, Galitski kontrakti: [diloviy tizhnevik], 30(845), pp. 26-33.

8. Available at: http: // www.ratingtop100.com/last-news/top-100.-luchshie-goroda-iregionyi-ukrainyi.html.

9. (2010), Kompleksna otsinka sotsialno-ekonomichnogo rozvitku regioniv Ukrayini za sIchen-berezen 2010 roku, available at: http://www.kmu.gov.ua/control/uk/.

10. Ageenko A.A. (2003), Metodologicheskie podhodyi $\mathrm{k}$ otsenke investitsionnoy privlekatelnosti otrasley ekonomiki regiona i otdelnyih hozyaystvuyuschih sub'ektov, Vopr. statistiki, 6. pp. 48-51.

11. Untura G.A. (2004), Analiz statisticheskih svyazey mezhdu reytingami investitsionnyimi klimatami fakticheskimi investitsiyami v regionah Rossii, Region: ekonomika i sotsiologiya, 1.

12. H.J. Westhoek, M. van den Berg, J.A. Bakkes (2006), Scenario development to explore the future of Europe's rural areas, Agriculture, Ecosystems \& Environment, 114(1), pp. 7-20.

13. Tempesta T., Vecchiato D., Girardi P. (2014), The landscape benefits of the burial of high voltage power lines: A study in rural areas of Italy, Landscape and Urban Planning, 126, pp. 53-64.

14. James E. Prieger (2013), The broadband digital divide and the economic benefits of mobile broadband for rural areas, Telecommunications Policy, 37(6-7), pp. 483-502.

15. Angelo Antoci, Simone Borghesi, Paolo Russu, Elisa Ticci (), Foreign direct investments, environmental externalities and capital segmentation in a rural economy, Ecological Economics, 116, pp. 341-353.

16. Emma L. Giles, Gary Bosworth, Joanie Willett (2013), The role of local perceptions in the marketing of rural areas, Journal of Destination Marketing \& Management, 2(1), pp. 4-13. 